\title{
OPTIMAL CREDIT GROWTH
}

\author{
G.A Diah Utari, Trinil Arimurti, Ina Nurmalia Kurniati'
}

\begin{abstract}
Banking credit has an important role in financing the national economy and as engine of economic growth. The high growth of credit is a commonly normal phenomenon as a positive consequence from the increase of financial deepening in economy. On the other hand, one must consider the implication of credit growth towards the financial stabilization and macro condition. Therefore, the policy authority should be able to identify the credit growth that is considered to be risky for the financial system and the macro stability. This research measures the credit growth without negative impact towards the economy and the banking condition. The testing uses Markov Switching (MS) Univariate approach and MS Vector Error Correction Model. The result with MS Univariate approach shows that the upper limit of the real credit growth in moderate regime is about 17.39 percent, while using the MS VECM approach is about 22.15 percent.
\end{abstract}

JEL classification : G21, E51, C23,C24

Keywords: bank, credit, risk, markov switching error correction model

1 Economic researchers at the Economic Research Group (GRE) of Bank Indonesia. The opinions expressed in this paper are solely those of the authors and do not necessarily reflect the views of Bank Indonesia. Acknowledgement and appreciation is offered to the head of GRE, Iskandar Simorangkir as well as SugiarsoSafuan, Reza Anglingkusumo and all other researchers at the Department of Economic Research and Monetary Policy, including WiwekoJunianto for assistance in the data collection process. The authors can be contacted at utari@bi.go.id, trinil@bi.go.id and inanurmalia@bi.go.id. 


\section{INTRODUCTION}

Banking credit has an important role in financing national economy and as the engine of the economic growth. The availability of credit enable households to consume more and enable company to invest which they cannot afford using their own fund. Besides, in the presence of moral hazard and adverse selection problems, which occurs commonly, the bank plays important role in capital allocation and supervision to ensure that public fund will be distributed to the most optimal benefited activities. Regardless the increasing financing role through capital market and bank and financing company, the banking credit still dominates the total credit to private sector with the average of $85 \%{ }^{2}$.

After decrease significantly during 2009 to first quarter of 2010 as a result of the global financial crisis, the credit growth increases again. At the end of 2011 the credit growth in nominal and real recorded for $24.7 \%$ and $20.1 \%$ consecutively, exceed the growth in 2010 of $23.5 \%$ and $15.3 \%$ (Figure 1). Up to March 2012, the nominal credit growth was $25 \%$, while the real credit growth was $20 \%$. The share of the credit to GDP by the end of 2011 was recorded by $20 \%$, increase significantly relative to its position in 2010 of $27 \%$ (Figure 2). The banking credit was estimated to keep growing amid decrease of BI rate.

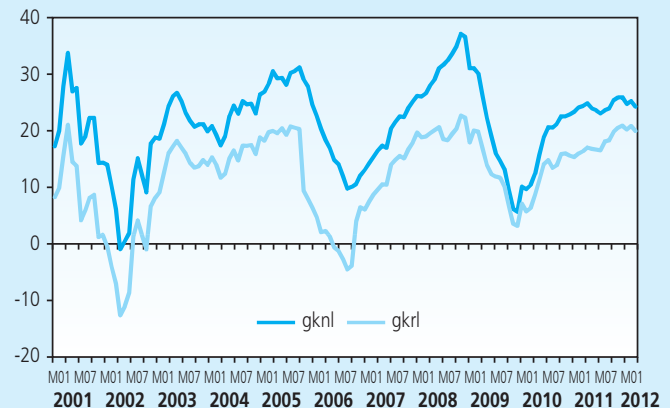

Figure 1. Credit Growth

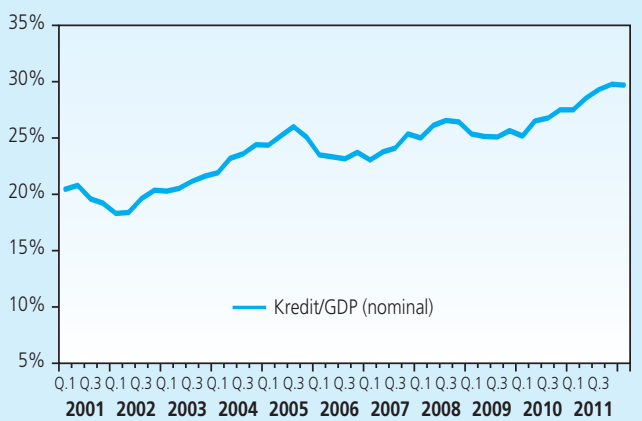

Figure 2. Credit / GDP (nominal)

The high credit growth was supported by the conducive economic condition which along 2011. The positive causality relationship between the economic and the credit growth reflect the existence of procyclicality relation between the two variables. This result is in line with several previous studies, which show that in long term the economic growth pushes the credit growth with the elasticity of more than one (Terrones and Mendoza, 2004) ${ }^{3}$. In Indonesia, the

2 Average of credit financing by banks to the private sectors compare with credit total to private sectors include credit by banks, leasing company, factoring, consumer financing and pawnshop since 1990 to 2010.

3 Other literatures found conversely where credit pushes economic growth, among others Beck, Levine and Loayza (2000), and Rajan and Zingales (2001). 
causality relationship tends to show the dominant role of the economic growths as the lead variable, rather than the credit growth ((Nugroho and Prasmuko (2010) and Utari et.al. (2011)).

On one hand, the rapid credit growth is a normal phenomenon and is a positive consequence from the increase of financial deepening in economy. On the other hand however, this credit growth has direct implication to the financial stability and the macro condition particularly when the rapid credit growth is followed by a weakening current account and vulnerable financial sector. This leads to the question of what is the rate of credit growth considered to be conducive for the economic growth and will not create pressure toward the inflation and the banking micro condition. The assessment for the credit growth is not only related to the amount distributed, but also its sectoral distribution.

According to several literatures, excessive credit growth can threaten the macroeconomic stability. The increase of credit especially consumptive one may trigger the growth of aggregate demand higher than the potential output which causes the economics to overheat. This in turn will increase of inflation, current accountdeficit as well as exchange rate appreciation. Simultaneously, during expansion period, the banking institution tends to have over optimistic expectation on the ability of the customer to pay, hence is careless in allocating credit for the high risk group. This type of credit will accumulate and potentially turn to be a bad loan during the economic contraction period.

The lesson learned from the earlier global financial crisis was the importance of the policy authority in supervising the risk from excess credit distribution. This is because the excessive aggregate credit is often related to the systemic risk. Therefore the policy authority is advised to identify the level of credit growth which is considered to be risky for financial system and macro stabilization. Another important thing is the countercyclical macroprudential policy to anticipate the risk from excessive of credit growth. Maintaining the financial system stability particularly for the bankingsector in this context is not only to ensure the banking sector both in aggregate or individually, to have good solvency during the period of distress, but also to have sufficient capital in keeping the allocation of the credit for the economy.

Based on the considerations above, the purposes of this research is to calculate the level of credit growth that is considered not to have negative impact on the economy and the banking condition. The presentation of this paper is as follows; the next session discusses the literature review on basic theory related to the credit, the financial and macro stability as well as the credit threshold. The third session will elaborate the development of credit in Indonesia. Methodology and data is presented in session four, while session five explains the empirical result. The conclusion and recommendation will close the presentation of this paper. 


\section{LITERATURE REVIEW}

\subsection{Credit Growth, Financial System Stability and Macro Stability}

The episodes of rapid credit growth - "credit boom" - posed a policy dilemma. Credit boom is defined as: 1) a period when there was a fairly extreme deviation from the credit growth to its long-term historical pattern that was not supported by the fundamentals (losifov and Khamis, 2009) and 2) an episode when credit growth to the private sector exceeded growth in a normal business cycle (Mendoza and Terrones, 2008). More credit means increasing access to finance and greater support for investment and economic growth. But these conditions may lead to the vulnerability of the financial sector through the loosening of lending standards, excessive leverage and asset price bubbles (Reinhart and Rogoff, 2009.)

Rapid credit growth could be triggered by several factors (Dell'Ariccia, et al, 2012): 1) part of the normal phase of a business cycle, 2) financial liberalizations and 3) surges in capital inflows. As explainedin the Dell Ariccia (2012), under normal conditions, as domestic economic improve, the credit will generally grow faster. This is generated by the firm's investment needs both in the form of new investment and capacity expansion. Rapid credit growth is also generated by financial liberalizations, which is initially intended to foster the financial deepening. Another factor contributing to credit growth is the capital inflows. It will increase in the funds available to banks, then eventually increasing credit growth. Unlike the first three, credit growth generated by an excessive response of the financial sector agents will lead to excessive credit growth (credit boom). This condition is based on theory of financial accelerator ${ }^{4}$. It is found as the market imperfection due to asymmetric information and weak institutional. Besides three factors above, Terrones (2011) also suggests other factors are excessive response from financial sector agents due to changes in risk over time.

In some literature, excessive credit growth is often attributed as a key factor contributing to the crisis in the financial sector, particularly in emerging countries. Credit booms had also preceded many of the largest banking crises of the past 30 years: Chile (1982), Denmark, Finland, Norway and Sweden in 1990/91, Mexico (1994) Thailand and Indonesia (1997/98) (Dell Aricia, et al, 2012). Kaminsky, Lizondo and Reinhart (1997) found that five of the seven studies surveyed prove credit growth is one determinant of the financial or banking crisis. Craig et al (2006) and Hardy and Pazarbasiouglu (1998) in Craig et al (2006) found that deterioration in business cycle and crisis in emerging markets are commonly preceded by a period of rapid credit growth and asset price bubbles. Similar results were also obtained from the study Goldstein (2001), IMF (2004a) and Mendoza and Terrones (2008). Goldstein (2001) proved the relation between the credit boom and the possibility of a twin crisis (financial and banking crisis). IMF found that three-fourth of the period of credit boom in the sample of emerging countries is associated with the banking crisis, while seven-eighths is associated with the financial crisis.

4 Financialacceleratorisa mechanism whichthe development ofthe financialsectormay affectthe business cycle (Fischer, 1933 in Penetta and Angelini, 2009). 
Meanwhile, Mendoza and Terrones (2008) found that for emerging markets, approximately $68 \%$ of the boom sare associated with foreign exchangecrises, 55\% with banking crises, and $32 \%$ withsudden stops.

A significant expansion in credit growth generally will increase the vulnerability of the financial system. This condition is driven by the behavior of banks which tend to be pro cyclical. The pro-cyclicality characteristic of the banking sector through their lending is an element of the systemic risks that need to be highly considered by the authorities. There fore, one goal of the macroprudential policy is to create the incentives for the financial sector to be less procyclical (Gersl and Jakubic 2010 in Frait et al, 2011).

As shown in Figure 21 were explored in a paper Frait et al, (2011), during the expansion phase, the aggregate demand will significantly increase, as well as the growth of bank lending and the economic leverage. This condition is usually accompanied by an increase in corporate profits, asset prices and consumer expectations. The surge in asset prices will increase collateral so that the new credit will be more easily administered and encourage banks and customers to be more willing to take risks. In this phase, the accumulation of the risks will be materialized in the case of the economic downturn. Increased household and corporate leverage/indebtedness would increase the vulnerability to macroeconomic risk through excessive aggregate demand growth beyond the capacity of the economy and eventually lead to overheating pressures. Bank credits boost the consumption and imports with the subsequent effect in increasing current account deficit. The worsening sustainable current account deficit may lead to the reduction of the capital inflows and eventually affects the financial and banking sector health. This is possible since the market will reacts to the increased of macroeconomic conditions risk by adjusting their portfolio investment, including the ownership of the currencies.

Meanwhile, in terms of microeconomic views, higher debt stock put the borrowers exposed with interest rate and exchange rate risk (if credit is distributed in foreign currency). Without hedging the exposure, the vulnerability of the debtor to both risks would increase the credit risk. The increasing in debt payments due to the rising of interest rates or the currency depreciation may lead to serious implications for the credit portfolio of the bank and for the real economic activity. The household and the firm's budget will be allocated more to accommodate the rising of the debt burden. After the peak of the boom cycle ends, the company's profit decline and credit worthiness also decreased. Finally, this will increase the non-performing credits, and eventually affects the health of bank balance sheets.

Vulnerability in balance sheet of the banking, the financial system and the macroeconomic is related each other. The macroeconomic imbalances reflected in the sudden changes in interest rates and exchange rates may affect the debtor's ability to repay debt and at the same time raises concerns about the health of the financial sector. For example, sudden reversal capital inflow could lead to a hard landing in the economy and force the authorities to raise interest rates. These conditions will further put pressure on the banking sector through the 
credit risk resulting from an increase in interest rates, economic slowdown and declining of collateral value. On the other hand, concerns about the financial sector will encourage the macroeconomic instability due to market reaction.

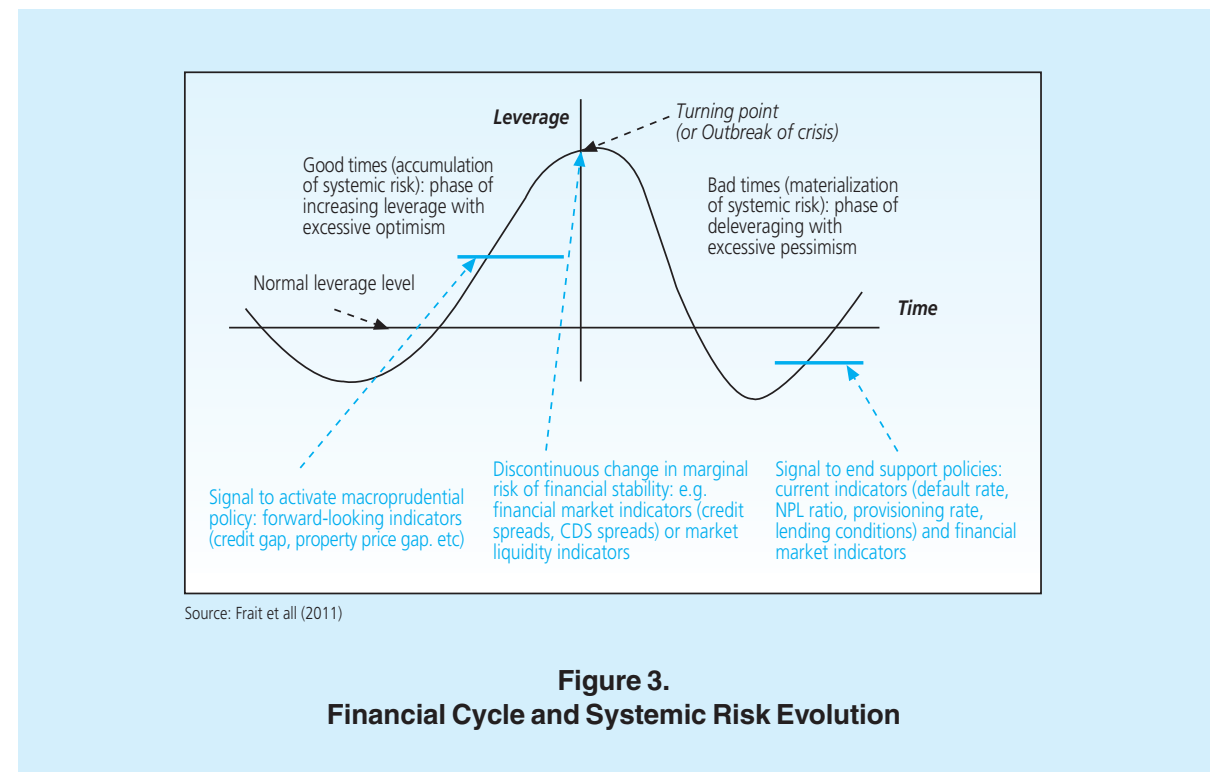

\subsection{Identification of Excessive Credit}

One way to identify the presence of excessive credit growth is to compare the credit growth within the same economic group levels. The credit to GDP ratio is widely used as a benchmark for the ability to repay. Therefore, countries with the same stage of the economy should have the same level of credit balance. Countries with low levels of the economy stage will naturally have a lower level of credit compared to the more developed countries. We can identify the credit threshold in the country by analyzing the trend of the credit to GDP ratio from countries within similar level of economic stage.

Another approach to identify the presence of the excess credit growth is the HP filter method. The trend estimated from HP Filter is regarded as equilibrium and the credit boom is defined as credit that exceeds a certain threshold around this trend. Threshold values can be defined as the relative deviation from the trend as used by Gourinchas et al. (2001) and IMF (2004). Nakornthab et al. (2003) have analyzed the trend component of the credit-to-GDP ratio with the estimate period 1951-2002. The main criticism of the methods of the HP filter that use only size of credit solely and do not take into account for the economic fundamentals that affect the balance of the credit stock.

Estimated credit equilibrium using fundamental economic variables are the most commonly used approach. Hofmann (2001) estimated the equilibrium level of credit to GDP ratio with 
VECM model. Boyssay et al. (2005) applied the model ECM and panel of credit data from Central and Eastern Europe countries. Backe et al (2005) estimated a panel model ECM on a combination of several OECD and emerging countries. Eller et al (2010) used VECM and estimated the long-term equation which is the demand side credit and short-term equation is the supply side of the credit. Short-term dynamics are modeled by Markov switching error correction that allows the credit coefficient varies according to its regime. Egert et al (2006) in Kelly et al (2011) using the panel out-of-sample to estimate the balance of credit in countries with transition economies.

\section{METHODOLOGY AND DATA}

This paper will analyze the excessive credit by using HP Filter. In addition we also use the equilibrium approach of the credit demand and supply, using fundamental variables, which is estimated using Markov Switching Vector Error Correction Model (MSVECM). Both approaches rely on information in the past.

\subsection{HP Filter Analysis}

As mentioned in the previous chapter, one of the methods to identify the presence of excess credit growth is the Hodrick Prescott filter (HP filter) approach. HP filter introduced by Hodrick and Prescott (1980), is a flexible detrending method and is commonly used in economic research.

Suppose a data series $y_{t}$ can be separated into 2 components, namely trend $\left(g_{t}\right)$ and cycle $\left(c_{t}\right)$ and written as $y_{t}=g_{t}+c_{t}$. HP Filter method to separate components of the cycle by solving the following optimization of the loss function, which is also known as the two sides HP filter approach:

$$
\min _{\left\{g_{t}\right\}_{t=1}^{T}} \sum_{t=1}^{T}\left(y_{t}-g_{t}\right)^{2}+\lambda \sum_{t=1}^{T}\left(g_{t+1}-2 g_{t}+g_{t-1}\right)^{2}
$$

where $\lambda$ (lambda) is the smoothing parameter. The first term of equation (1) measure the accuracy of the model, or in other words the penalty for the variance of the cyclical component. The second term is penalty of smoothness level of the trend. Therefore there is a conflict between a smoothness trend and its good ness of fit, where $\lambda$ is the "trade off" parameter that can be. If $\lambda$ is zero then the trend component will be equal to the original data, and if it is infinite, $(\lambda \rightarrow \infty)$, then the trend will converge to the linier trend $\left(g_{t}=\beta * t\right)$.

Hodrick and Prescott suggest $\lambda=1600$ for quarterly data, and is the standard for business cycle analysis. Value of $\lambda$ assumes the business cyclehas a frequency of approxi matel y 7.5 years. Ravnand Uhlig (2002) from Drehman and Borioet al (2010) showedthat the value of $\lambda$ 
should be adjusted if the frequency of data changes. Convention researchers proposed value $\lambda=100$ forannual data, $\lambda=1600$ for quarterly data, and $\lambda=14,400$ for monthly data.

Undeniably, the HP filter method also has some disadvantagesas proposed by Cottarellietal. (2005); first the HP filter measure the trend of the overall observations and ignores the possibility of a structural break; second, the HP filter is sensitiveto the bias of the tip point. If the start or the end pointof the data does notreflectthe same thing inthecycle, then it tends tobiasupward /downward; third, the HPfilteris sensitive to the selection of time duration. Gourichasetal (2001) conducted a rolling HP filter and found that the HP filter estimation resultscan bevery different from theex-post trend estimation and, fourth, the HP filter sensitive to the smoot hingpara meter $(\lambda)$ used.

Inthis paper, the excessive credit growth will be analyzed by looking at the deviation of the long-term trend (using HP filter) to the credit growth, and also credit-to-GDP ratioand its deviation from the long-term trend. Usingthe ratio of credit to GDP is following theapproach proposed by the Basel Committee on Banking Supervision (2010). Following the IMF (2004), the thre shold level used is 1 and 1.75 times standard deviation of thelong-term trend.

\begin{tabular}{|c|c|c|c|c|}
\hline \multicolumn{5}{|c|}{$\begin{array}{c}\text { Table } 1 . \\
\text { Data for HP Filter Test }\end{array}$} \\
\hline & Data Aggregate & Source Data & Frequency & Observation Period \\
\hline- & Real Credit Growth* & $\mathrm{BI}$ & Monthly & Jan 2001-May 2012 \\
\hline- & Ratio Credit/Nominal GDP & $\mathrm{BI}$ & Quarterly & Q1.2001-Q1 2012 \\
\hline
\end{tabular}

\subsection{MSVAR}

Markov Switching (MS) model from Hamilton (1989), also known by the model of regime switching is one of the popular non-linear time series model. This model contains several structures (equations) which describe the characteristics of time series data in different regimes. By doing switching between the structures, the model is expected to capture a more complex dynamics. The main feature of MS is switching mechanism controlled by unobservable state variable that follows Markov chain of order 1. In general, the general nature of Markov is that the present value is affected by the value of the past. MS may explain the correlated data showing the dynamic pattern at some period of time. MS model has been widely applied to analyze time series data and financial economics.

MS-VAR model provides a framework for analyzing multivariate (and univariate) representation, in the presence of regime switching. MS-VAR model is a dynamic structure that depends on the value of the state variable $\left(S_{t}\right)$, which controls the switching mechanism between some state (regime). A common form of MS-VAR models are: 


$$
y_{t}=v\left(s_{t}\right)+A_{1}\left(s_{t}\right) y_{t-1}+\cdots+A_{p}\left(s_{t}\right) y_{t-p}+\varepsilon_{t}
$$

Where $\left(y_{t}=\left(y_{1 t}, \ldots, y_{n t}\right)\right.$ isan $n$, dimensional vector time series, is a vector of various intercepts, $a_{-} 1, \ldots$, is amatrix containing $A_{1}, \ldots, A_{p}$ auto regressive para meters, and $\varepsilon_{t}$ is random error.

In equation (2) the first term on the right, $v\left(S_{t}\right)$, is assumed to vary according to its state. Specifications switching using the intercept are used in cases where the transition from the mean of the other state is assumed to follow a smooth trajectory. Alternative representations can be used if we assume the mean changes or varies following his state. Specifications are useful when there is a leap in the mean after the switch of regime.

In Krolzig (1997) illustrated the two regimes Markov Switching AR 1 with switching mean and volatility as follows:

$$
y_{t}=\mu_{S_{t}}+A\left(y_{t-1}-\mu_{S_{t-1}}\right)+u_{t} \sim N I D\left(0, \sigma_{S_{t}}^{2}\right)
$$

where and $\mu_{S_{t}}=\mu_{0}\left(1-S_{t}\right)+\mu_{1} S_{t}$ dan $\sigma_{S_{t}}^{2}=\sigma_{0}^{2}\left(1-S_{t}\right)+\sigma_{1}^{2} S_{t}$

In each specification, MS assume that unobserved regime $S_{t}$ follow the Markov degree one, hence the current regime $S_{t}$ depends on the regime of the previous period $S_{t-1}$. The probability of transition from the regime of $S_{t-1}$ to $S_{t}$ can bedenoted by:

$$
P\left(S_{t}=j \mid S_{t-1}=i\right)=p i j
$$

Where $P_{i j}$ is the probability of state/ followed state $j$ with $p_{i i}+p_{i j}=1$ and $0<p_{i j}<1$. (i, $\mathrm{j}$ $=0,1$ ). The notation in the form of the transition matrix Pis as follows.

$$
\left(\begin{array}{l}
P\left(S_{t}=i\right) \\
P\left(S_{t}=j\right)
\end{array}\right)=\left(\begin{array}{ll}
p_{i i} & p_{j i} \\
p_{i j} & p_{j j}
\end{array}\right)\left(\begin{array}{l}
P\left(S_{t-1}=i\right) \\
P\left(S_{t-1}=j\right)
\end{array}\right)
$$

Estimates of transition probabilities $P_{i j}$ is generally solved numerically with Maximum Like lihood Estimator.

The conditional probability density function on observation $y_{t}$ as the function of current statevariable $S_{t}, S_{t-1}$, and the previous observation is:

$$
\begin{aligned}
& F_{t-1}=\left\{y_{t-1}, y_{t-2}, \ldots\right\}=f\left(y_{t} \mid S_{t}, S_{t-1}, F_{t-1}\right) \\
& =\frac{1}{\sqrt{2 \pi \sigma_{S_{t}}^{2}}} \exp \left(-\frac{\left[y_{t}-\mu_{S_{t}}-A\left(y_{t-1}-\mu_{S_{t-1}}\right)\right]^{2}}{2 \sigma_{S_{t}}^{2}}\right)
\end{aligned}
$$

and because. $\quad u_{t}=y_{t}-\mu_{S_{t}}-A\left(y_{t-1}-\mu_{S_{t-1}}\right) \sim N I D\left(0, \sigma_{S_{t}}^{2}\right)$. 
Chain rule for conditional probabilities is valid so:

$f\left(y_{t}, S_{t}, S_{t-1} \mid F_{t-1}\right)=f\left(y_{t} \mid S_{t}, S_{t-1}, F_{t-1}\right) P\left(S_{t}, S_{t-1} \mid F_{t-1}\right)$

such that the log-like lihood functionis optimized

$l(\theta)=\sum_{t=1}^{T} l_{t}(\theta)$

where

$$
\begin{aligned}
& l_{t}(\theta)=\log \left(\sum_{S_{t}=0}^{1} \sum_{S_{t-1}=0}^{1} f\left(y_{t} \mid S_{t}, S_{t-1}, F_{t-1}\right) P\left(S_{t}, S_{t-1} \mid F_{t-1}\right)\right) \\
& \theta=\left(p_{00}, p_{11}, A, \mu_{0}, \mu_{1}, \sigma_{0}^{2}, \sigma_{1}^{2}\right)
\end{aligned}
$$

Chain ruleis used toobtain the conditional joint probability $P\left(S_{t}, S_{t-1} \mid F_{t-1}\right)$.

$$
P\left(S_{t}, S_{t-1} \mid F_{t-1}\right)=P\left(S_{t} \mid S_{t-1}, F_{t-1}\right) P\left(S_{t-1} \mid F_{t-1}\right)
$$

And because of the characteristic of Markov $P\left(S_{t} \mid S_{t-1}, F_{t-1}\right)=P\left(S^{t} \mid S_{t-1}\right)$, so

$$
P\left(S_{t}, S_{t-1} \mid F_{t-1}\right)=P\left(S_{t} \mid S_{t-1}\right) P\left(S_{t-1} \mid F_{t-1}\right)
$$

If the joint probabilityat time $t$ is known then the like lihood $l_{t}(\theta)$ can be calculated. The Maximum Like lihood Estimates for $\theta$ is obtained from the it erationto maximize the like lihood function. The like lihood function is updated on eachiteration.

Let $P\left(S_{0}=1 \mid F_{0}\right)=P\left(S_{0}=1\right)=\pi$ is known, hence $P\left(S_{0}=0\right)=1-\pi$. Then the probability $P\left(S_{t-1} \mid F_{t-1}\right)$ and joint probability $P\left(S_{t}, S_{t-1} \mid F_{t-1}\right)$ can be calculated using the following algorithm:

1. $P\left(S_{t-1}=i \mid F_{t-1}\right), i=0,1$, at period $t$

$$
P\left(S_{t}=j, S_{t-1}=i \mid F_{t-1}\right)=P\left(S_{t}=j \mid S_{t-1}=i\right) P\left(S_{t-1}=i \mid F_{t-1}\right)
$$

2. As $y_{t}$ is known, then the information $F_{t}=\left\{F_{t-1}, y_{t}\right\}$ can be updated, hence we can calculate its probability as follows:

$$
\begin{array}{r}
P\left(S_{t}=j, S_{t-1}=i \mid F_{t}\right)=P\left(S_{t}=j, S_{t-1}=i\right) P\left(S_{t-1}=i \mid F_{t-1}\right) \\
=\frac{f\left(y_{t}\left|S_{t}=i, S_{t-1}=j, y_{t}\right| F_{t-1}\right)}{f\left(y_{t} \mid F_{t-1}\right)} \\
=\frac{f\left(y_{t} \mid S_{t}=j, S_{t-1}=i, F_{t-1}\right) P\left(S_{t}=j, S_{t-1}=i \mid F_{t-1}\right)}{\sum_{S_{t-1}=0}^{1} f\left(y_{t} \mid S_{t}, S_{t-1}, F_{t-1}\right) P\left(S_{t}=s t, S_{t-1}=s t-1 \mid F_{t-1}\right)} \\
P\left(S_{t}=s t \mid F_{t}\right)=\sum_{S_{t-1}=0}^{1} P\left(S_{t}=s t, S_{t-1}=s t-1 \mid F_{t-1}\right)
\end{array}
$$


Probability of Steady state: $P\left(S_{0}=1, \mid F_{0}\right)$ and $P\left(S_{0}=0, \mid F_{0}\right)$

$$
P\left(S_{0}=1, \mid F_{0}\right)=\frac{1-p 00}{2-p 00-p 11} \text { and } P\left(S_{0}=0, \mid F_{0}\right)=\frac{1-p 11}{2-p 00-p 11}
$$

The data used in this studyis the monthly real credit data from January 2003 to March 2012. This period waschosen to eliminate the impact of the Asian crisis. The data sourceis from Bank Indonesia.

\subsection{MS VECM}

In this research, empirically weal so test the credit thre shold using multivariate analysis that takes into account the variable of the demand and the supply of credit. From this empirical analysis, wewill also analyze the determinants of changesin credit, both in the short and in the long-term.

MSVECM Analysis consists of 2 stages namely the analysis Vector Error Correction Model (VECM) followed by the analysis of Markov Switching. VECMVAR model is designed for useina data series that is not stationary and is known to have acointegration relationship. InVECM, there are specifications that limit the long-term behavior of the endogenous and exogenous variables to converge to its cointegration relations hipsbut allow dynamic adjustments in the short term. In cointegration, there is error correction term, since the deviation from the longterm equilibriumis gradually corrected through the short-term adjustment. MS-VECM is actually a VECM with shif tingpara meters. Following Krolzig (1997), VECMfor variables I (1)can be mode ledinto

$$
\Delta x_{t}=v\left(s_{t}\right)+\alpha\left(s_{t}\right)\left(\beta x_{t-1}\right)+\sum_{i=1}^{k-1} \Gamma_{i}\left(\Delta x_{t-i}\right)+u_{t}
$$

where $\Delta x_{t}$ is a vector of dimensionless variables $m, v\left(S_{t}\right)=$ is the regime dependent intercept $\Gamma i$, is matrix of parameters and error variance is allowed to change over regime ut $\sim\left(0, \Sigma\left(s_{t}\right)\right)$. In this term, $\alpha\left(s_{t}\right)$ is the matrix of adjustment parameters, and $\beta$ is the matrix of long-term parameters (co-integration vectors).

Steps undertaken in the VECM analysis can be displayed in the following chart:

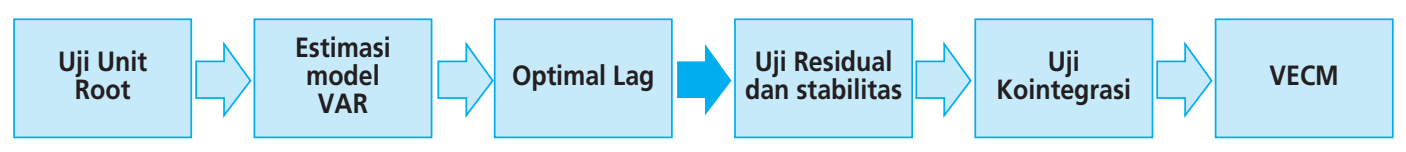


Before applying the co-integration test, we need to do some preliminary testing. First, the optimal lag test was done to overcome the problem of autocorrelation and heteroscedasticity (Gujarati, 2003). Determination of the optimal lag is important because when the lag is too long will reduce the degrees of freedom, while the too short lag will result in an incorrect specification model (Gujarati, 2003). The determination of optimal lag is based on five criteria, namely the sequential modified LR test statistic, Akaike Information Criterion (AIC), Schwarz Information Criterion (SC), Final Prediction Error (FPE), and Hannan-Quin Information (HQ). From these criteria, we will use the criterion that gives the shortest lag. Further tests carried out in the form of residual correlogram. VAR system of equations passes the test if the correlation between the lag and the variables are within the specified range.

After making various preliminary tests, the co-integration test can be performed. If it found co-integration vector, weak exogeneity test would then perform to ensure the longterm causality and to check whether there is feedback from the short-term variables to the dependent variable. Weak exogeneity of each variable is done by restricting $\alpha \_i=0$, where $\alpha$ is a vector of adjustment coefficients and $i=1,2,3$. If the zero restriction is not rejected, it means the variable has no feedback to the past deviations from long-term relationships (weakly exogenous).

Meanwhile, the existence of co-integration relationship does not necessarily mean that the equilibrium exist in the model. Co-integration is able to capture the long-term relationship between dependent and explanatory variables, however it cannot capture how the dynamic response of the dependent variable due to the changes in the explanatory variables. To capture the response, we use the error correction framework, which is Vector Error Correction Model (VECM). The short-term models that contain error correctionterm show how the adjustment mechanism to return to equilibrium when the dependent variable is disturbed by the exogenous shock. After conducting co-integration and weak exogeneity test, VECM estimation performed by the following equation:

$$
\Delta x_{t}=\mu_{0}+\sum_{i=1}^{k-1} \Gamma_{i} \Delta x_{t-1}+\delta E C T_{t-1}+e_{t}
$$

where ECT is the error correction term derived from the co-integration vector; $\delta$ error correction coefficient which shows the response of dependent variable in each period t. In other words, $\delta$ shows the speed of adjustment back to its equilibrium and has to be negative and significant, and no larger than one. In the case of disequilibrium, the negative value indicates the correction process. Meanwhile, the low value of $\delta$ closed to zero means that the dynamic effects dominate the behavior of the credit growth in the short term. Instead, if $\delta$ is larger and closed to one then the long-term effects dominate the behavior of credit growth in the short term, or simply the short-term dynamics has a small effect on the growth of credit.

Based on the linear VECM estimation, analysis is continued to estimate the MS- VECM to examine the relationship between the variables that affect the demand for credit. 


\section{Long-Term Credit Equation: Cointegration}

To analyze the behavioral changes of the optimal credit for the economy, both at macro and micro level of banking, we adopt the model proposed by Psaradakis et al (2004), which is also used by Eller et al (2010). We use the following framework: (i) the credit has a long-term relationship with the fundamental macroeconomic variables (demand for credit) and in the short term is influenced by banking micro variables (supply for credit), (ii) the adjustment of the volume of credit on its equilibrium may not be linear because there is a period where the credit markets are in disequilibrium point, and the factors affecting the credit possibly change over time.

Equation of demand for creditwe use in this paper refers to the following model of Eller et al (2010):

$$
\log \left(K r l_{t}\right)=\alpha_{0}+\alpha_{1} \log (P D B r l)_{t}+\alpha_{2} r_{t}+\alpha_{3} \pi_{t}+\varepsilon_{t}
$$

Where $\mathrm{Krl}$ is the total use of credit volume in real term after deflated with $\mathrm{CPI}, \mathrm{PDBrl}$ is the real GDP interpolatedin to monthly data, $r_{t}$ is mortgage interest rate (as a proxy for the price of the credit), and $\pi_{t}$ is the annual CPI inflation .

\begin{tabular}{l|c|l|c}
\multicolumn{4}{c}{ Table 2. } \\
\multicolumn{1}{c|}{ Data for Long Term Equation } \\
Variable & Source Data & \multicolumn{1}{|c}{ Frequency } & Observation Period \\
\hline Real Credit $(\mathrm{Krl})$ & $\mathrm{BI}$ & Monthly & Jan 2003-Mar 2012 \\
\hline GDP real $(\mathrm{PDBrl})$ & $\mathrm{BI}$ & Monthly (Interpolated) & Jan 2003-Mar 2012 \\
\hline Inflation $(\pi)$ & $\mathrm{BI}$ & Monthly & Jan 2003-Mar 2012 \\
\hline Interest rate of credit $(\mathrm{r})$ & $\mathrm{BI}$ & Monthly & Jan 2003-Mar 2012 \\
& & &
\end{tabular}

Parameter for $\mathrm{PDBrl}$ is expected to be positive, showing the increasing economic activity leads to the increase of demand for credit. Parameter value for variable $r$ tis expected to be negative, showing higher credit interest rateswill reduce demand for credit since the costof fundincrease. Parameters of $\pi$ is also expectedto be negative, in line with the Elleretal (2010) that negative relationship between inflation andcredit demand can be viewed from two aspects : first, when the inflation has reacheda certain level, it will beassociated with inflation volatility that significantly disturbs the function of financial markets due to the increase of uncertainty. Second, if the nominalin terest rate is high, even real interest rate is low, the economic agent swill choose credit swith short duration, which in turn limitsthe volume of distributed credits. 


\section{EquationShort TermCredits}

If the variables in the equation (20) have the cointegration relationship then we can construct the following short-term dynamic error correction equation:

$$
\Delta \log \left(K r l_{t}\right)=\beta_{0}+\beta_{1} \varepsilon_{t-1}+\beta_{2}{ }^{\prime} \Delta Z_{t}+\beta_{3} \Delta \log \left(K r l_{t-1}\right)+u_{t}
$$

Where $\Delta \log \left(\mathrm{Krl}_{t}\right)$ is areal credit growth, $\varepsilon_{t-1}$ is the previous error correction term of the long-term equation, $\beta_{1}$ is the speed of adjustment parameter to the long-terme quation, and $Z_{t}$ isset of other possible explanatory variables.

Vector $Z_{t}$ contains short-term determinants of the credits, consisting of third-party funding and credit risk. Third party fund sare expected to havea positive relationship since the increase of the available funds may also increase the distributed credit. For credit risk, we use the ratio of Non-Performing Loan (NPL) to total assets. The expected relationship of this variable is negative because the increasing non-performing loan leads to the decline of bank's willing ness to distribute the credit.

The above short-term equation is based on the assumption that the process of adjustment to the equilibriumis with in the same regime. We can relax this assumption using MSVECM framework by allowing parameters to change according to its unobservable state. Within the framework of MSVECM above, the short-term equation can be transformed into:

$$
\begin{aligned}
& \Delta \log \left(K r l_{t}\right)=\beta_{0 s t}+\beta_{1 s t} \varepsilon_{t-1}+\beta_{2 s t}{ }^{\prime} \Delta Z_{t}+\beta_{3 s t} \Delta \log \left(K r l_{t-l}\right)+u_{t} \\
& \text {, for every st=1, 2, dst }
\end{aligned}
$$

where the short-term equation is conditional on theunobservable regime variable $s_{t}$.

\section{EMPIRICAL RESULTS}

\subsection{HP Filter Analysis}

Analysis result using HP filter approach shows that the real growth of credit in Indonesia is still within the range of its long term trend either using the upper or the lower limit of 1 standard deviation or using the IMF standard of 1.75. We can observe that the real credit growth until May 2012 by $20.7 \%$ remains in the long term range and relatively lower than the credit growth in the end of 2008, which was closed to the upper limit (Figure 4). Looking at its disaggregation, the growth of credit investment, working capital credit and consumption credit remain in the long-term trend (Figure 5 up to Figure 7). 


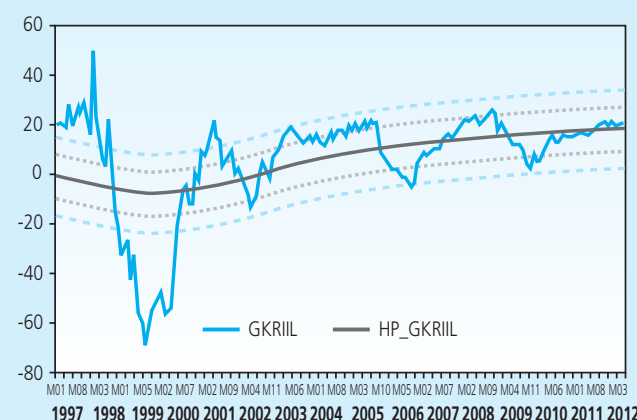

Figure 4.

Long Term Trend of Real Credit Growth

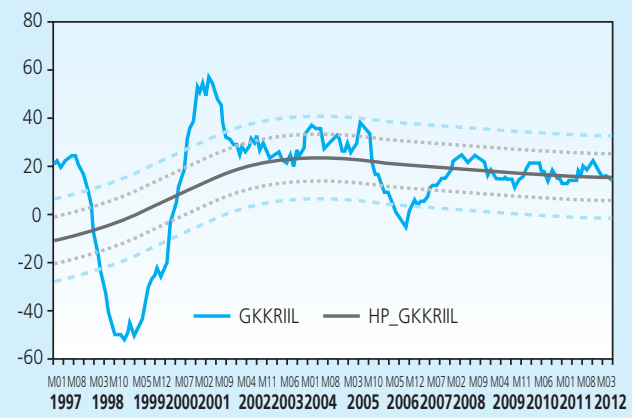

Figure 6.

Long Term Trend of Real Consumption Growth

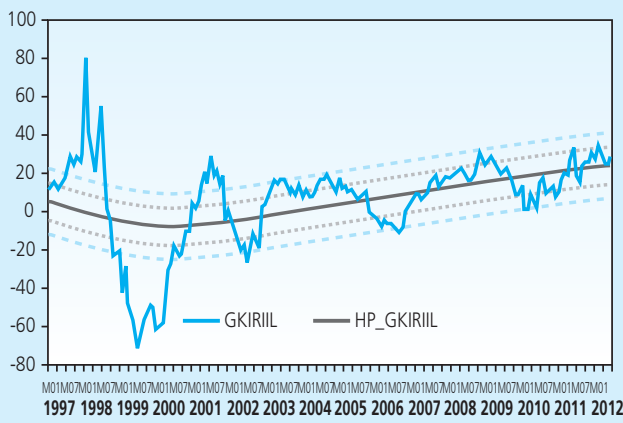

Figure 5.

Long Term Trend of Real Investment Growth

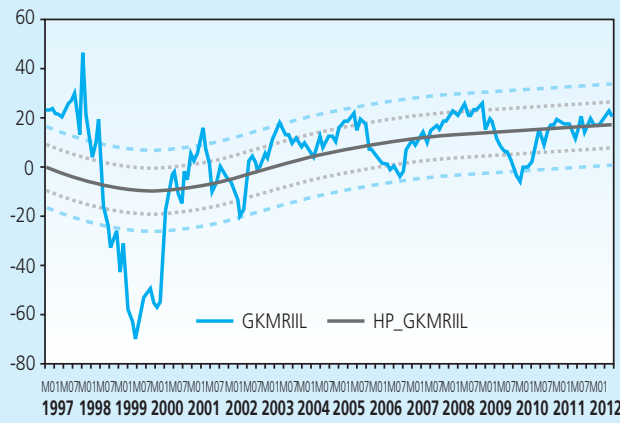

Figure 7.

Long Term Trend of Real Working Capital Growth

However as explained by Cottarelli et al. (2005), one of the HP Filter weaknesses is measuring the trend from overall observation and ignores the possible existence of structural break. Considering this, we try to eliminate the data during the crisis, and sub sequently, the HP Filter test is applied on the data for the period of January 2001 up to May 2011

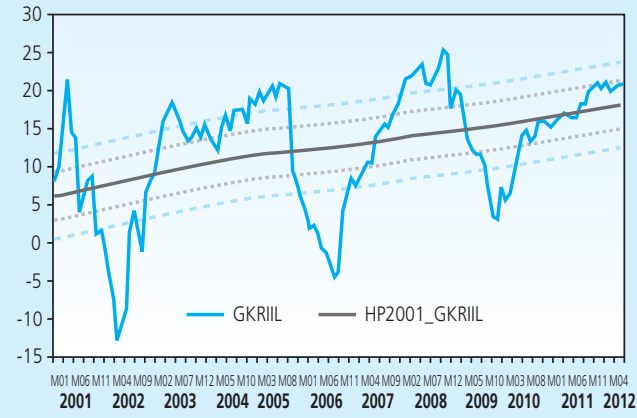

Figure 8.

Long Term Trend of the Real Credit Growth after Crisis

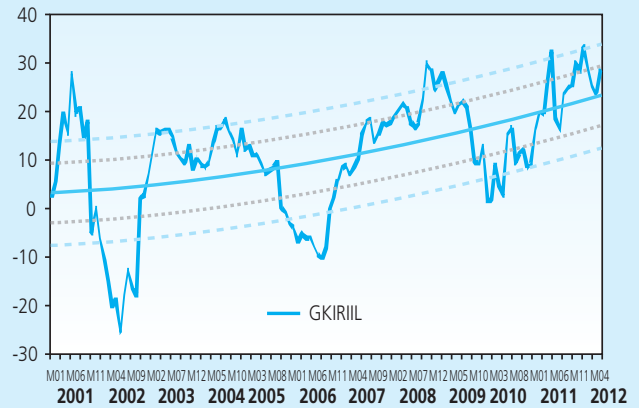

Figure 9.

Long Term Trend of Real Investment Credit Growth after Crisis 


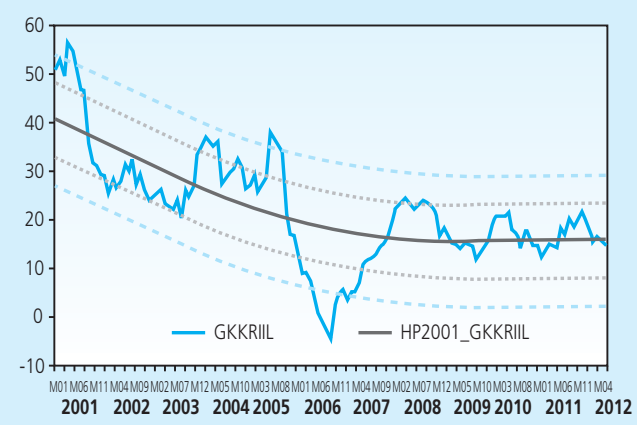

Figure 10.

Long Term Trend of Real Consumption Credit Growth after Crisis

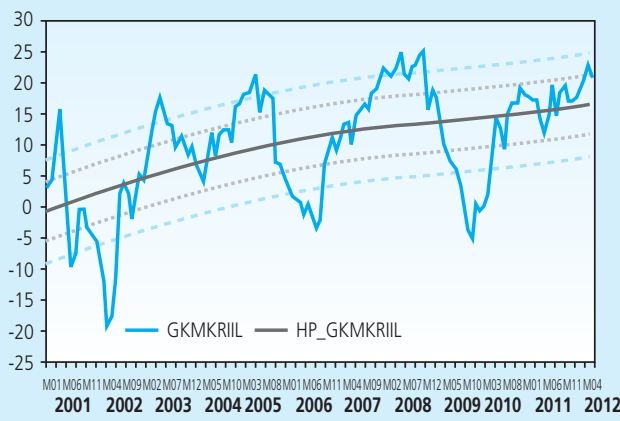

Figure 11.

Long Term Trend of Real Working Capital Credit Growth after Crisis

Considering the after crisis period to obtain the long-term trend, it shows that the real growth of the total credit has reached the upper limit when using 1 standard deviation limit, but remain relatively under control when using 1.75 standard (Figure 8). The credit which grew above the upper limit of 1 standard deviation is working capital and investment credit (Figure 9 and Figure 11). Meanwhile consumption credit remains in the range of its long term trend.

Another approach to observe the excessive credit growth is by using the long term trend of the total credit to GDP ratio in nominal. BCBS which proposed countercyclical capital buffer policy stated that the use of credit to GDP ratio has several advantage compared to credit growth ${ }^{5}$, which are: i) there is a strong relationship between the banking crisis and the credit growth to GDP ratio, which exceed its long term average, ii) by being stated in ratio, then this variable has already been normalized by the economic measurement, therefore the ratio is not influenced by cyclical pattern of credit demand.

For the after crisis period, Figure 12 shows that the credit to GDP ratio remain in the range of its long term trend even it tends to be in the upper limit. If it is compared to the previous year, the growth of credit to GDP ratio keeps increasing since December 2009 until it reaches $29.73 \%$ in the end of first quarter 2012. The movement of the working capital credit ratio and the investment credit to GDP is easier to reach the upper and the lower limit of its long term trend (Figure 13 and Figure 15). This contradicts the consumption credit which tends to be stable ( Figure 14 ). The economic condition seems highly influence the working capital credit ratio and investment credit on GDP.

5 Drehman, Borio, Gambacorta, Jimenez and Trucharte (2010) "Countercylical Capital Buffer : Expoloring Options", BIS Working Paper No. 317. 


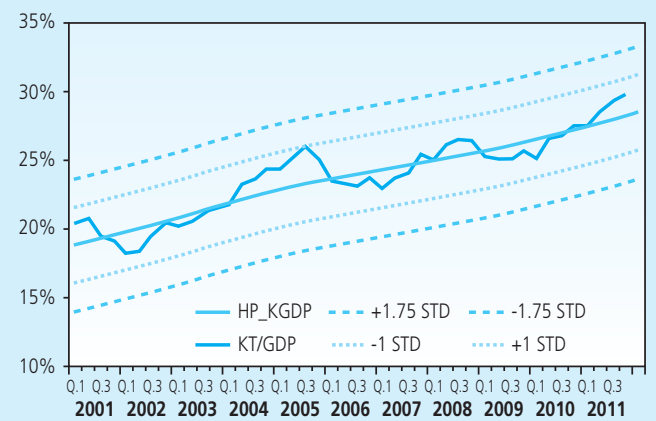

Figure 12.

Long Term Trend of Credit to GDP ratio after Crisis

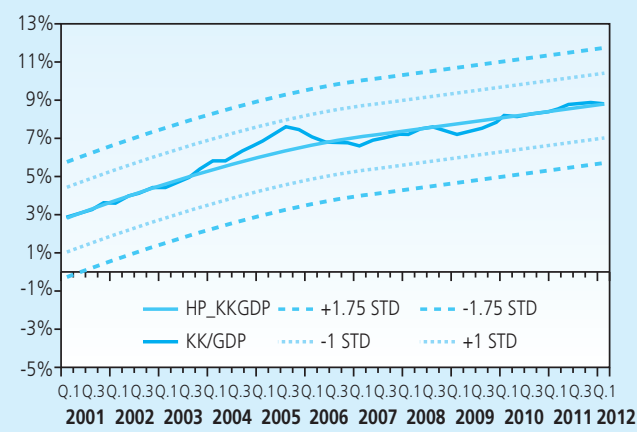

Figure 14.

Long Term Trend of Investment Credit to GDP Ratio, after Crisis

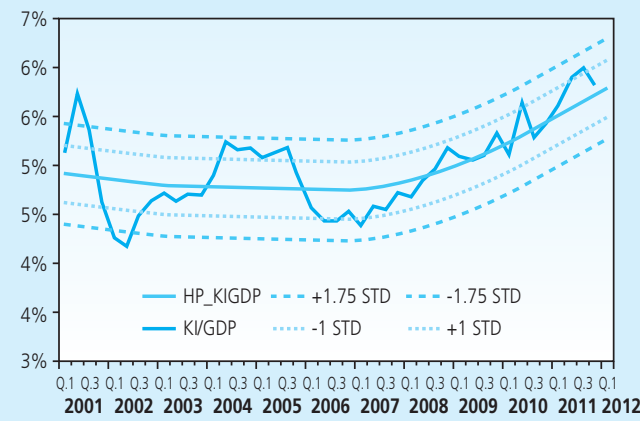

Figure 13.

Long Term Trend of Investment Credit to GDP ratio, after crisis

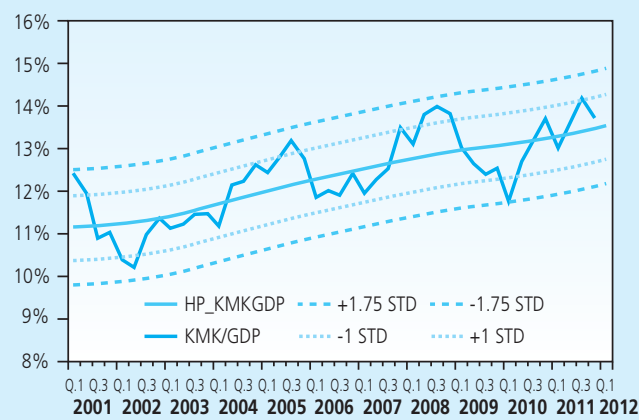

Figure 15.

Long Term Trend of Working Capital Credit to GDP ratio, after Crisis

\subsection{Univariate Analysis of Real Credit Growth}

Markov Switching (MS) analysis ${ }^{6}$ of real credit growth data (univariate) shows that real credit growth (January 2003 to March 2012) can be modelled with MSI(3)AR(0), data time series with 3 regimes. Figure 16 as well as Tables 3 and 4 summarise the chronology of regime changes in the period of observation. 


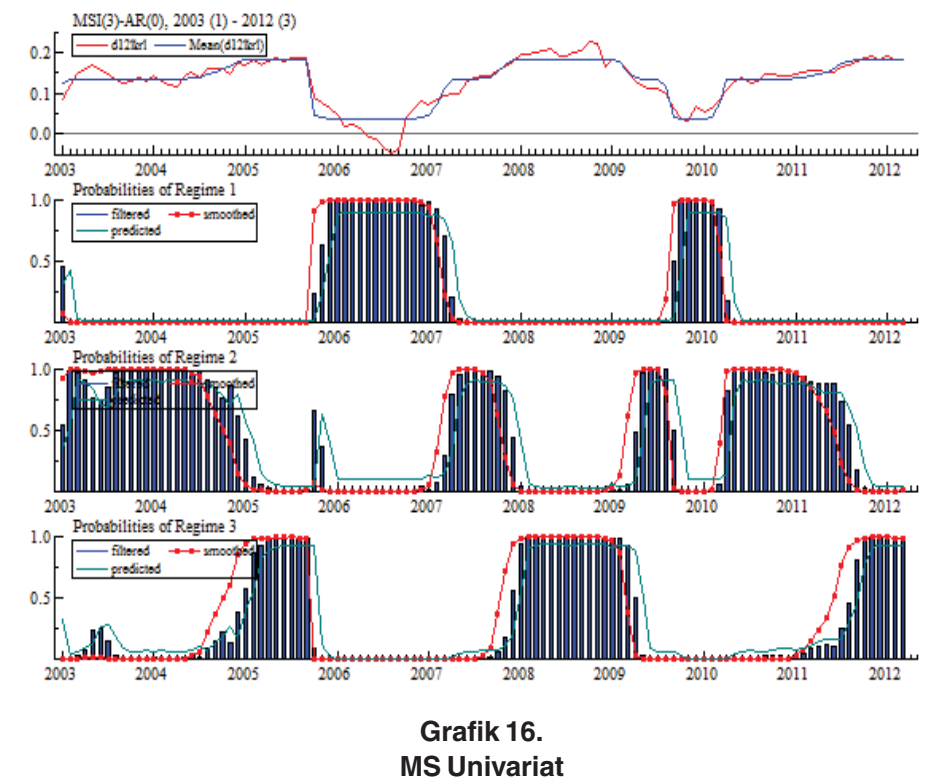

\begin{tabular}{l|l|l}
\multicolumn{1}{c}{ Regime 1 } & Regime 2 & Regime 3 \\
\hline $2005: 10-2007: 2$ & $2003: 1-2004: 9$ & $2004: 10-2005: 9$ \\
\hline $2009: 9-2010: 3$ & $2007: 3-2007: 10$ & $2007: 11-2009: 2$ \\
\hline & $2009: 3-2009: 8$ & $2011: 6-2012: 3$ \\
\hline Mean: 0.038 & $2010: 4-2011: 5$ & \\
\hline Stdev: 0.041 & Mean: 0.134 & \\
\hline
\end{tabular}

Table 4. Regime Specification

Matrix of Probability Transition

\begin{tabular}{l|c|c|c} 
& Regime 1 & Regime 2 & Regime 3 \\
Rezim 1 & 0.906 & 0.094 & 0.000 \\
\hline Rezim 2 & 0.023 & 0.915 & 0.062 \\
\hline Rezim 3 & 0.025 & 0.032 & 0.943
\end{tabular}

Predicted Regime Probabilities ( $\mathrm{t}+1)$

\begin{tabular}{c|c|c} 
Regime 1 & Regime 2 & Regime 3 \\
0.000 & 0.0062 & 0.9938
\end{tabular}

\section{Regime Statistic}

\begin{tabular}{l|r|c|c} 
& nObs & Prob & Duration \\
Regime 1 & 23.6 & 0.203 & 10.66 \\
\hline Regime 2 & 49.2 & 0.383 & 11.81 \\
\hline Regime 3 & 38.1 & 0.413 & 17.49
\end{tabular}

\section{Coefficient}

\begin{tabular}{l|c|c|c} 
& Mean & SE & T-val \\
Regime 1 & 0.038 & 0.0062 & 6.268 \\
\hline Regime 2 & 0.134 & 0.0048 & 28.261 \\
\hline Regime 3 & 0.183 & 0.0053 & 34.348
\end{tabular}


Regime 3 is a high real credit growth regime with a mean of $18.3 \%$. Regime 2 is a moderate real credit growth regime with a mean of $13.4 \%$ and regime 1 is alow real credit growth regime with a mean of $3.8 \%$.

Assuming real credit growth in moderate regime is the "normal" condition, the statistical information gleaned from the regime can be used for the upper and lower limits of real credit growth. Based on the statistics, it can be suggested that the upper bound for real credit growth is $17.39 \%$ and the lower bound is $9.5 \%$ ( $\mu \pm 20$ ).

The results of MS indicate that the probability of credit growth in the subsequent month stay in high regime is $99.4 \%$.

\subsection{MS VECM Analysis}

To identify the long term relationship of the credit volume, we estimate the demand credit equation. The use of the concept is expected to provide us the insight of possible excess credit. As explained in previous chapter, the test involves stationarity test, optimal lag measurement, residual test, co-integration test, and sub sequently the VECM estimation.

Unit root test is conducted using the Augmented-Dickey-Fuller (ADF) test and the PhillipsPerron (PP) test for null hypothesis of the existence of unit root. Visual inspection to the variables shows the existence of trend in real credit volume and real GDP volume, while it does not exist in inflation and the credit interest rate. The unit root test results, as presented in Table 5, show that nearly all variables I (1) are significant at a level of 5\% and stationary in the first difference.

Table 5. Unit Root Test

\begin{tabular}{c|c|r|r|r|r|r|r} 
& \multicolumn{4}{|c|}{ Augmented Dickey-Fuller test statistic } & \multicolumn{4}{c}{ Phillips-Perron test statistic } \\
\cline { 2 - 8 } & Exogenous & Lag (SIC) & t-Stat & Prob. & Exogenous & Adj. t-Stat & Prob. \\
\hline $\log (K r l)$ & $\mathrm{C}, \mathrm{T}$ & 0 & -2.389 & 0.384 & $\mathrm{C}, \mathrm{T}$ & -2.453 & 0.351 \\
\hline$\Delta \log (K r l)$ & $\mathrm{N}$ & 5 & -2.205 & 0.027 & $\mathrm{~N}$ & -9.714 & 0.000 \\
\hline $\log (P D B r l)$ & $\mathrm{C}, \mathrm{T}$ & 10 & -1.913 & 0.643 & $\mathrm{C}, \mathrm{T}$ & -3.169 & 0.095 \\
\hline$\Delta \log (P D B r l)$ & $\mathrm{C}$ & 12 & -2.589 & 0.098 & $\mathrm{C}$ & -11.031 & 0.000 \\
\hline$r$ & $\mathrm{C}$ & 2 & -1.853 & 0.354 & $\mathrm{C}$ & -2.704 & 0.076 \\
\hline$\Delta r$ & $\mathrm{~N}$ & 0 & -3.125 & 0.0020 & $\mathrm{~N}$ & -10.102 & 0.000 \\
\hline$\pi$ & $\mathrm{C}$ & 1 & -2.343 & 0.1603 & $\mathrm{C}$ & -2.301 & 0.173 \\
\hline$\Delta \pi$ & $\mathrm{N}$ & 0 & -9.664 & 0.0000 & $\mathrm{~N}$ & -9.636379 & 0.0000 \\
\hline
\end{tabular}

After ensuring that the data used in this analysis is stationary at the first difference, the next step is to determine the optimal lag from the VAR equation. The number of optimal lag is determined using the criteria as in Attachments. The Schwarz Information criteria indicate a lag of two while the Hannan-Quin Information suggests four and Akaike Information seven. From the analysis of residuals, the correlation test provides evidence of autocorrelation in the 
residuals for VAR with a lag of two, while the test using a lag of four gives no evidence of autocorrelation. $^{7}$ Therefore, an optimal lag of four is selected for this research.

From the cointegration test using lag 4, the Trace test shows two cointegrating vectors, while the $\lambda_{\max }$ test (see Attachment) indicates one cointegrating vector. The difference that emerges from the trace test and $\lambda_{\max }$ test is attributable to problems with the limited size of the sample or the deterministic model used. Considering that this research focuses specifically on the lessons to be learnt regarding credit, the results of the $\lambda_{\max }$ test are used with one cointegrating vector.

The cointegrating vectors or the results of the VECM estimation (where the parameter $\log (K r l)$ is equal to 1$)$ are as follows:

\begin{tabular}{|c|c|c|c|}
\hline \multicolumn{4}{|c|}{ Table 6. Co-integration Vector } \\
\hline Variable & Coefficient & SE & T-Stat \\
\hline $\log (P D B r l)_{t-1}$ & -1.799 & 0.101 & $-17.869 * * *$ \\
\hline$r_{t-1}$ & 0.033 & 0.009 & $3.431 * * *$ \\
\hline$\pi_{t-1}$ & 0.019 & 0.004 & $4.818^{* * *}$ \\
\hline$E T C_{t-1}$ & -0.110 & 0.036 & $-3.087^{* * *}$ \\
\hline
\end{tabular}

The signs of the parameters in Table 6 are as expected. In the long-term, demand for credit is positively affected by economic activity, while lending rates and inflation have a negative effect.

Furthermore, this research will conduct a weak exogeneity test, which is equivalent with the speed of adjustment coefficient test of equals to zero. In co-integrated system, if variable does not respond on the discrepancy to the long term, then the variable is weakly exogenous. This means there is no lost information if this variable is not modeled; hence can be in the right side of the VECM. We can see below that some speed of adjustment coefficient from the variables is weakly exogenous.

\begin{tabular}{c|c|c|c|}
\multicolumn{5}{c}{ Tabel 7. Speed of Adjustment $(\alpha)$} \\
Variable & $\alpha$ & Standard error & t-statistic \\
\hline $\log (\mathrm{Kr} l)$ & -0.110 & 0.036 & -3.087 \\
\hline $\log (\mathrm{PDBrl})$ & 0.018 & 0.017 & 1.097 \\
\hline$r$ & 0.222 & 0.239 & 0.931 \\
\hline$\pi$ & -6.145 & 2.327 & -2.641 \\
\hline
\end{tabular}

7 However, in the correlogram test, autocorrelation is present in PDBrl to PDBrl lag 3, 6, etc, this is probably because the interpolation of PDBrl (quarterly) to become monthly. 
These results are in line with the weak exogeneity test $^{8}$ for each variable as Table 8 below:

\begin{tabular}{c|c|c}
\multicolumn{3}{c}{ Table 8. } \\
Weak Exogeneity Test \\
Variable & p-value & LR statistic \\
\hline $\log (\mathrm{Kr} l)$ & 0.023 & 5.201 \\
\hline $\log (\mathrm{PDBrl})$ & 0.260 & 1.271 \\
\hline$r$ & 0.417 & 0.658 \\
\hline$\pi$ & 0.047 & 3.957
\end{tabular}

and are exogenous variables because their p-values are higher than the $5 \%$ level of significance, however, this is not the case for the demand for credit and inflation variables.

The test for the null hypothesis that all speed of adjustment coefficient except for the credit demand is zero generating $p$-value $=0.108$ and $R$ stat 6.067 . It means that null hypothesis is not rejected and thus variable beyond credit are stated weakly exogenous and no lost information if the equations are not modeled and all variables can be in the right side of VECM.

The estimation of the error correction model of the demand for credit can be expressed as follows:

\begin{tabular}{|c|c|c|c|}
\hline \multicolumn{4}{|c|}{ Table 9. VECM Model } \\
\hline Variabel & Koefisien & SE & T-Stat \\
\hline C & 0.008 & 0.002 & 3.290 *** \\
\hline$E C T_{t-1}$ & -0.110 & 0.004 & $-3.087^{* * *}$ \\
\hline$\Delta \log \left(K r l_{t-1}\right)$ & -0.058 & 0.078 & -0.748 \\
\hline$\Delta \log \left(K r l_{t-2}\right)$ & -0.201 & 0.078 & $-2.576^{* * *}$ \\
\hline$\Delta \log \left(K r l_{t-3}\right)$ & 0.093 & 0.078 & 1.182 \\
\hline$\Delta \log \left(P D B r l_{t-1}\right)$ & 0.218 & 0.169 & 1.283 \\
\hline$\Delta \log \left(P D B r l_{t-2}\right)$ & -0.498 & 0.179 & $-2.775^{* * *}$ \\
\hline$\Delta \log \left(P D B r l_{t-3}\right)$ & 0.912 & 0.172 & $5.312 * * *$ \\
\hline$\Delta \log \left(r_{t-1}\right)$ & -0.021 & 0.015 & -1.451 \\
\hline$\Delta \log \left(r_{t-2}\right)$ & 0.026 & 0.018 & 1.477 \\
\hline$\Delta \log \left(r_{t-3}\right)$ & 0.005 & 0.017 & 0.302 \\
\hline$\Delta \log \left(\pi_{t-1}\right)$ & 0.001 & 0.001 & -0.881 \\
\hline$\Delta \log \left(\pi_{t-2}\right)$ & -0.001 & 0.001 & -0.755 \\
\hline$\Delta \log \left(\pi_{t-3}\right)$ & 0.002 & 0.001 & 1.700 * \\
\hline
\end{tabular}

8 Where $\mathrm{HO}$ for this test is the coefficient of the speed of adjustment in the short-run equation with the dependent variables equal to zero. 
The coefficient of the error correction term is negative and significant, which indicates that disequilibrium in the short term will be adjusted to its long term relationship. The cointegration relationship is presented in Figure 17 which shows the stationary of the co-integration vector.

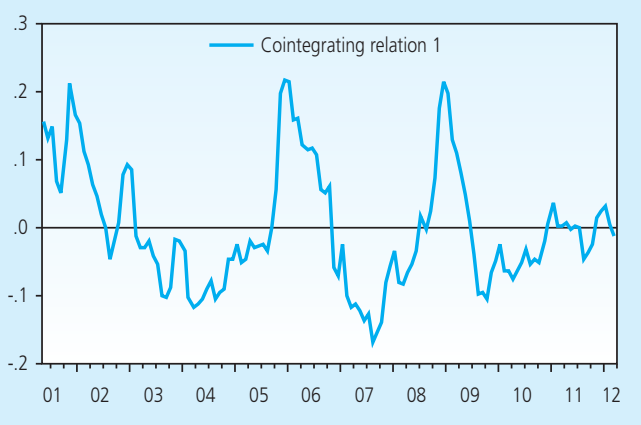

Figure 17.

Cointegration

To inline the analysis of VECM with the previous analysis, therefore it is necessary to complete it with the analysis of annual model of real credit, $\Delta_{12} \log (\mathrm{Krl})$. According Angling kusumo (2005), this can be done by adjusting the error correction term, from $E C T_{t-1}$ to $E C T_{t-13}$. The estimation of supply of credit $\Delta_{12} \log (\mathrm{Krl})$ can be expressed as follow:

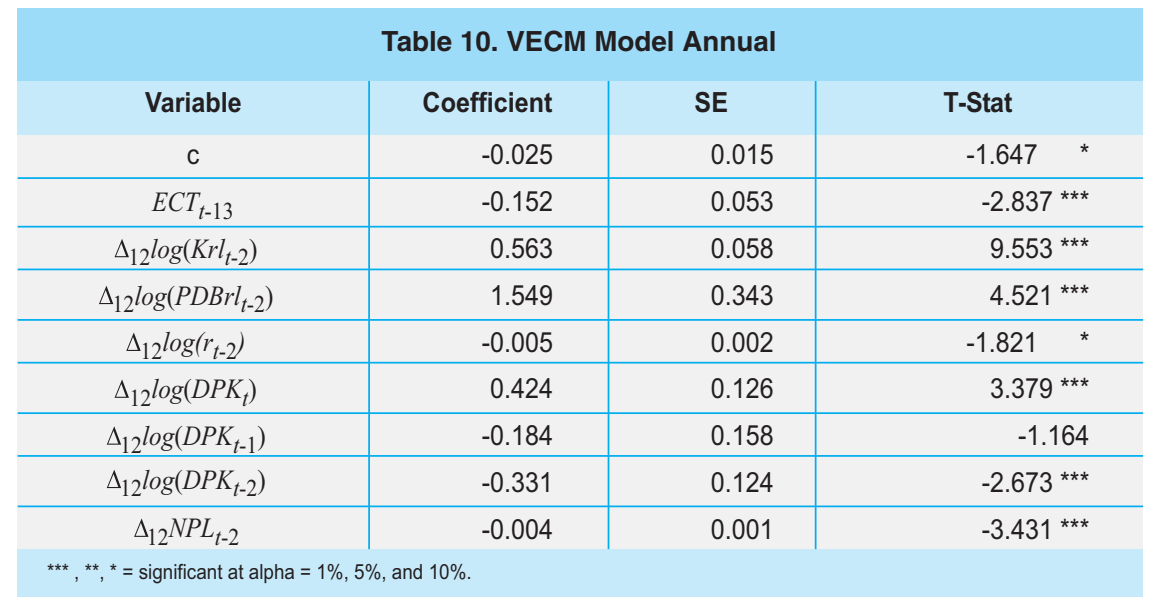

The parameters in Table 10 above show the expected signs. In the near term, credit growth is positively and significantly affected by past credit growth, economic growth and growth of third party fund. Meanwhile, changes in lending rates and non-performing loans negatively and significantly affect credit growth. 
The Linear model of $\Delta_{12} \log \left(\mathrm{Krl}_{\mathrm{l}}\right)$ above is continued by conducting MS analysis where the parameters of each variable are allowed to change according to their unobservable state. The results of MS for real credit growth and its determinants show that real credit growth (January 2003 to March 2012) can be modelled using MSIA (3) ARX (0), time series data that contain autoregressive parameters in 3 regime. Regime 1 is the low real credit growth regime with a mean of $8.1 \%$. Regime 2 isthe moderate real credit growth regime with a mean of $14.7 \%$. Meanwhile, Regime 3 is the high real credit growth regime with a mean of $16.7 \%$.

\begin{tabular}{|c|c|c|c|c|c|c|c|c|c|}
\hline \multicolumn{10}{|c|}{ Table 11. Annual MSVECM Model } \\
\hline & c & $E C T_{t-13}$ & $\Delta_{12} \log \left(K r l_{t-2}\right)$ & $\Delta_{12} \log \left(P D B r l_{t-2}\right)$ & $\Delta_{12} \log \left(r_{t-2}\right)$ & $\Delta_{12} \log \left(D P K_{t}\right)$ & $\Delta_{12} \log \left(D P K_{t-1}\right)$ & $\Delta_{12} \log \left(D P K_{t-2}\right)$ & $\Delta_{12} N P L_{t-2}$ \\
\hline \multirow{2}{*}{$\begin{array}{l}\mathrm{R} \\
1\end{array}$} & 0.036 & -0.038 & 0.204 & -0.937 & -0.024 & 0.6211 & 0.018 & -0.115 & -0.009 \\
\hline & 0.159 *** & 0.026 & $0.065^{* * *}$ & $0.398^{* *}$ & $0.003^{\star \star \star}$ & $0.107^{* * *}$ & 0.160 & 0.116 & $0.001^{* * *}$ \\
\hline \multirow{2}{*}{$\begin{array}{l}R \\
2\end{array}$} & 0.035 & -0.0544 & 0.496 & 1.352 & -0.002 & 0.176 & -0.1324 & -0.301 & 0.002 \\
\hline & $0.0139^{* *}$ & 0.034 & $0.050^{\star \star \star}$ & $0.239^{* \star *}$ & 0.002 & $0.099 *$ & 0.138 & $0.109^{\star * *}$ & $0.001^{* * *}$ \\
\hline \multirow{2}{*}{$\begin{array}{l}\mathrm{R} \\
3\end{array}$} & 0.028 & -0.128 & 0.6225 & 0.4481 & 0.002 & -0.16 & 0.116 & 0.131 & -0.002 \\
\hline & 0.0223 & $0.042^{* * *}$ & $0.113^{\star * *}$ & 0.3361 & 0.004 & 0.107 & 0.095 & 0.093 & 0.002 \\
\hline
\end{tabular}

It can be observed from the result above that real GDP growth (PDBrl), third party fund (DPK) and non-performing loans (NPL) influence the demand for credit in low and moderatecredit growth regime. In regime 3 (high), only long-term variables and past credit growth affects the demand for credit. The variable $E C T_{t-13}$, which is only negative and significant in the third regime, indicates that long-term correlation persists and not broken.

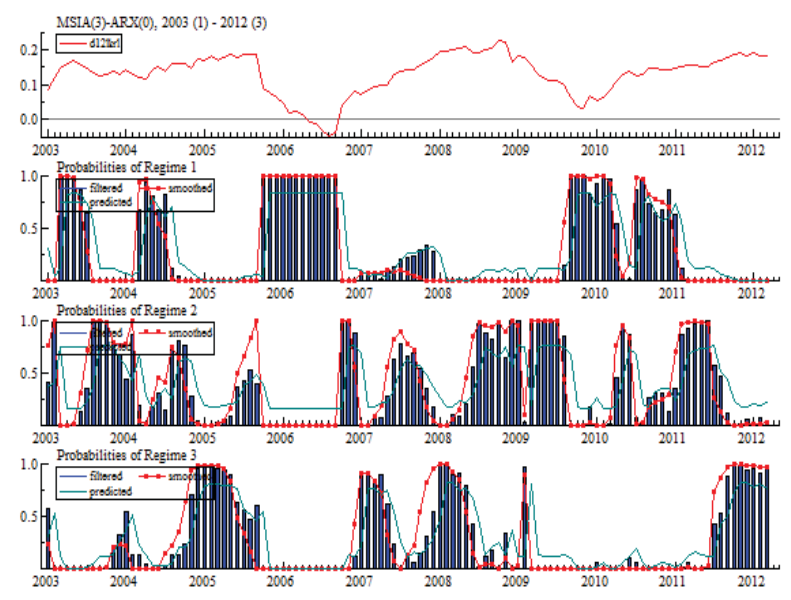

Grafik 18.

MS-VECM 


\begin{tabular}{l|l|c}
\multicolumn{3}{c}{ Table 12. MSIA(3) ARX(0) Regime } \\
\hline \multicolumn{1}{c|}{ Regime 1 } & Regime 2 & Regime 3 \\
\hline $2003: 3-2003: 6$ & $2003: 1-2003: 2$ & $2004: 10-2005: 5$ \\
\hline $2004: 3-2004: 7$ & $2003: 7-2004: 2$ & $2007: 1-2007: 4$ \\
\hline $2005: 10-2006: 9$ & $2004: 8-2004: 9$ & $2007: 10-2008: 5$ \\
\hline $2009: 8-2010: 3$ & $2005: 6-2005: 9$ & $2009: 2-2009: 2$ \\
\hline $2010: 7-2010: 12$ & $2006: 10-2006: 12$ & $2011: 7-2012: 3$ \\
\hline & $2007: 5-2007: 9$ & \\
\hline & $2008: 6-2009: 1$ & \\
\hline & $2009: 3-2009: 7$ & \\
\hline & $2010: 4-2010: 6$ & \\
\hline Mean:0.081 & $2011: 1-2011: 6$ & Mean:0.167 \\
\hline Stdev:0.063 & & Stdev:0.035 \\
\hline
\end{tabular}

Table 13. Regime Specification

Probability Transition Matrix

\begin{tabular}{l|c|c|c} 
& Reg 1 & Reg 2 & \multicolumn{1}{|c}{$\operatorname{Reg} 3$} \\
Reg 1 & 0.084 & 0.162 & 0.002 \\
\hline Reg 2 & 0.117 & 0.759 & 0.124 \\
\hline Reg 3 & 0.000 & 0.168 & 0.831
\end{tabular}

Predicted Regime Probabilities (t+1)

\begin{tabular}{r|r|r} 
Regime 1 & Regime 2 & Regime 3 \\
0.0026 & 0.1804 & 0.817
\end{tabular}

\section{Regime Statistic}

\begin{tabular}{l|c|c|r} 
& nObs & Prob & \multicolumn{1}{|c}{ Duration } \\
Reg 1 & 33.7 & 0.289 & 6.11 \\
\hline Reg 2 & 45.9 & 0.407 & 4.15 \\
\hline Reg 3 & 31.4 & 0.303 & 5.93
\end{tabular}


Assuming that real credit growth in regime 2 is "normal" condition, the statistical information gleaned from regime 2 can be used to discern the upper and lower thresholds of real credit growth. Accordingly, the upper and lower limits of real credit growth based on the statistics of regime 2 are $22.15 \%$ and $6.8 \%$ respectively ( $\mu \pm 2$ ó).

The result of MS show that the probability of credit will stay in the high regime in the subsequent month is $81.7 \%$.

\section{CONCLUSION AND RECOMMENDATIONS}

This analysis on this paper provide 4 (four) results; first, in general, based on HP Filter approaches, during the period of January 1997 - May 2012, the real credit growth and its disaggregation still remain in the range of its long-term trend. However, after crisis period (January 2001 - May 2012) the total credit growth, working capital credit, and investment credit have crossed the upper limit threshold of 1 standard deviation from the long-term trend. Credit to GDP ratio after crisis still remain in the range of its long term trend, though the investment credit to GDP ratio tends to remain in the upper limit. Second, the analysis of univariate Markov Switching (MS) shows that the real credit growth follows a 3 regimes model (low, moderate, high). The upper limit of the real credit growth for the moderate regime is $17.39 \%$. Third, there is a co-integration relationship between the real credit growth with the real GDP, the inflation, as well as the credit interest rate. In the long term, credit demand is positively influenced by the economic activities and negatively influenced by the credit interest rate and inflation. While in the short term the credit growth is influenced by NPL ratio and third party funds. Fourth, the analysis of Markov Switching VECM shows that the real credit growth can be modeled into 3 regimes model (low, moderate, high). The upper limit of themoderate real credit growth is $22.15 \%$.

This paper has open enough room for future studies. The value of the threshold provided in this study is only early indicators. It is necessary for the policy maker to make a judgment on determining the threshold of the excessive credit growth by considering other banking micro indicators and other factors such as credit allocation, sectoral credit concentration, etc. Related to the Markov Switching model, the improvement of the model is possible by applying multivariate Markov switching simultaneously between the credit and the other macroeconomic variables (e.g. inflation). 


\section{REFERENCES}

Anglingkusumo, Reza (2005). "Money - Inflation Nexus in Indonesia: Evidence From a P-Star Analysis". Tinbergen Institute Discussion Paper.TI 2005-054/4.VrijeUniversiteit Amsterdam

Bry, Gerhard and Boschan, Charlotte (1971). "Cyclical Analysis of Time Series: Selected Procedures and Computer Programs". Technical Paper No. 20, National Bureau of Economic Research, New York.

Beck, T.,R. Levina and N. Loayza, 2000, "Finance and The Source of Growth", Journal of Finance and Economics, 58, p. 261-300.

Burns, Arthur and Mitchell, Wesley (1946)."Measuring Business Cycles".National Bureau of Economic Research.

Boissay F., Calvo-Gonzales., Kozluk T. (2005), "Is Lending in Central and Eastern Europe Developing Too Fast ?", European Central Bank.

Cotarelly C., Dell' Ariccia G., Vladkova-Hollar I. (2005), "Early Birds, Late Risers and Sleeping Beauties: Bank Credit Growth to The Private Sector in Central and Eastern Europe and in the Balkans", Journal of Banking and Finance, 2009.

Den Heuvel, S. J. V. (2001). "The Bank Capital Channel of Monetary Policy, Mimeo. University of Penssylvania.

Eller, Markus.,Frommer, Michael., Srzentic, Nora.,(2010) ,"Private Sector Credit in CESEE: LongRun Relationships and Short-Run Dynamics"' Austrian Central Bank.

Frait, Jan., Gersl, Adam.,Seidler, Jacub. "Credit Growth and Financial Stability in the Czech Republic", Policy Research Working Paper 5771, World Bank.

Furlong, Frederick T. (1992), "Capital Regulation and Bank Lending" Economic Review Federal Reserve Bank of San Fransisco

Dell'Ariccia, Giovanni et all (2012), "Policies for Macrofinancial Stability : How to Deal with Credit Booms", IMF Staff Discussion Note No. SDN/12/06.Policies

Gambacorta, Leonardo. and Mistrully, Paolo E. , (2003)," Bank Capital and Lending Behaviour: Empirical Evidence for Italy". Bank of Italy

Gambacorta, Leondardo and Ibanez, David M. (2011), "The Bank Lending Channel : Lessons from The Crisis." BIS Working Paper No. 345. 
Goldstein, M, (2001),"Global Financial Stability : Recent Achievements and Ongoing Challenges," Global Public Policies and Programs : Implications for Financing and Evaluation, Proceedings from a World Bank Workshop (Washington), pp. 157-61

Gourinchasp.O., Valdes R., Landerretche O. (2001)." Lending Booms : Latin America and the World", Working Paper 8249. National Bureau of Economic Research.

Iossifov, Plamen and Khamis, May, 2009, "Credit Growth in Sub Saharan Africans : Sources, Risks and Policy Responses", IMF Working Paper WP/09/180.

International Monetary Fund (2004), "Are Credit Booms in Emerging Markets a Concern?" World Economic Outlook, April.

Jimenez,Gabriel., Steven, Ongena., José-Luis Peydró., and Saurina, Jesus., 2011," Macroprudential Policy, Countercyclical Bank Capital Buffers and Credit Supply: Evidence from the Spanish Dynamic Provisioning Experiments," Working Paper Bank of Spain

Kraft, Evan, and TomislavGalac, 2011, "Macroprudential Regulation of Credit Booms and Busts: the Case of Croatia," Policy Research Working Paper No. 5772 (Washington, DC: World Bank)

Krolzig, H.-M. (1997), "Markov Switching Vector Autoregressions: Modeling, Statistical Inference and Application to Business Cycle Analysis: Lecture Notes in Economics and Mathematical Systems", 454, Springer-Verlag, Berlin.

Krolzig, H.-M.(1998), "Econometric Modeling of Markov-Switching Vector Autoregressions Using MSVAR for Ox", Discussion Paper, Department of Economics, University of Oxford.

Lim, C , Columba, A et all (2011)," Macroprudential Policy : What Instruments and How to Use Them?" IMF Working Paper No. WP/11/238.

Guonan, Ma.,Xiandong, Yan., and Xi, Liu (2011)." China's Evolving Reserve Requirement", BIS Working Paper No. 360

Martin, Antoine.,Mc Andrews, James, and Skeie, David., "A Note on Bank Lending in Times of Large Bank Reserves", Federal Reserve Bank of New York Staff Reports, May 2011.

Mendoza, Enrique G., and Terrones, Marco E. "An Anatomy of Credit Booms : Evidence from Macro Aggregates and Micro Data", NBER Working Paper 14049

Niemira, Michael P. and Klein, Philip A. (1994)."Forecasting Financial and Economic Cycles", John Wiley and Sons, Inc, USA.Oxford.

Psaradakis, Z.,M. Sola and F. Spagnolo, 2004. "On Markov Error Correction Models, with an Application to Stock Prices and Dividends", Journal of Applied Econometrics 19(1). 69-88. 
Rajan, R.G. and Zingales L. 2001. "Financial Systems, Industrial Structure and Growth". Toward operationalizing macroprudentialpolicy; When to Act, Oxford Review of Economic Policy. 17(4) p. 461-482

Reinhart, Carmen M., and Kenneth S. Rogoff, 2009, "The Aftermath of Financial Crises,"NBER Working Paper No. 14656.

Tabak, Benyamin M., Noronha, Ana C. and Cajueiro, Daniel, 2011 " Bank Capital buffer, Lending Growth and Economic cyle : Empirical Evidence for Brazil", Central Bank of Brazil.

Tovar, Camilo., Garcia-Escribano, Mercedes., and Martin, Mercedes V. (2012), "Credit Growth and the Effectiveness of ReserveRequirements and Other Macroprudentiallnstruments in Latin America", IMF Working Paper No. WP/12/142. 


\section{ATTACHMENT}

\section{Lag Length Criteria}

VAR Lag Order Selection Criteria

Endogenous variables: LOG(KRIIL) LOG(PDBRL) IKWA INFY

Exogenous variables: $\mathrm{C}$

Date: 08/13/12 Time: 12:18

Sample: 2001M01 2012M03

Included observations: 127

\begin{tabular}{c|c|c|c|c|c|c} 
Lag & LogL & LR & FPE & AIC & SC & HQ \\
\hline 0 & -269.2697 & NA & 0.000869 & 4.303459 & 4.393040 & 4.339855 \\
\hline 1 & 620.0215 & 1708.559 & $9.26 \mathrm{e}-10$ & -9.449157 & -9.001253 & -9.267179 \\
\hline 2 & 676.6073 & 105.1516 & $4.89 \mathrm{e}-10$ & -10.08830 & $-9.282077^{*}$ & -9.760744 \\
\hline 3 & 693.9919 & 31.21011 & $4.79 \mathrm{e}-10$ & -10.11011 & -8.945559 & -9.636966 \\
\hline 4 & 729.3157 & 61.19088 & $3.55 \mathrm{e}-10$ & -10.41442 & -8.891549 & $-9.795696^{*}$ \\
\hline 5 & 746.9960 & 29.51363 & $3.48 \mathrm{e}-10$ & -10.44088 & -8.559688 & -9.676576 \\
\hline 6 & 756.8198 & 15.77990 & $3.86 \mathrm{e}-10$ & -10.34362 & -8.104101 & -9.433730 \\
\hline 7 & 788.8405 & $49.41785^{*}$ & $3.04 \mathrm{e}-10 *$ & $-10.59591^{*}$ & -7.998074 & -9.540443 \\
\hline 8 & 801.2941 & 18.43513 & $3.26 \mathrm{e}-10$ & -10.54006 & -7.583901 & -9.339011 \\
\hline
\end{tabular}

\section{Correlogram}

\section{Autocorrelations with 2 Std.Err. Bounds}

$\operatorname{Cor}(\operatorname{LOG}(\mathrm{KRIIL)}, \operatorname{LOG}(\mathrm{KRIIL)}(-\mathrm{i}))$

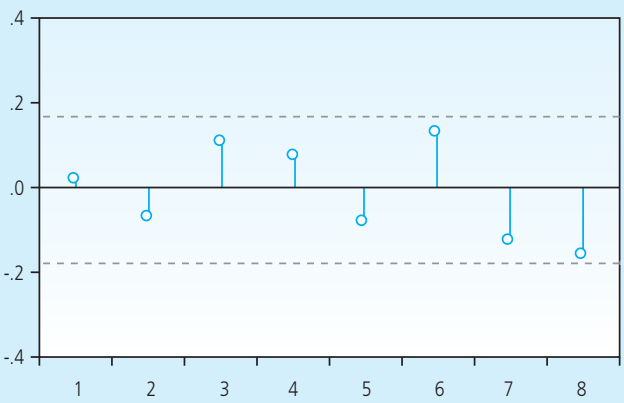

$\operatorname{Cor}(\operatorname{LOG}($ KRIIL),LOG(PDBRL)(-i))

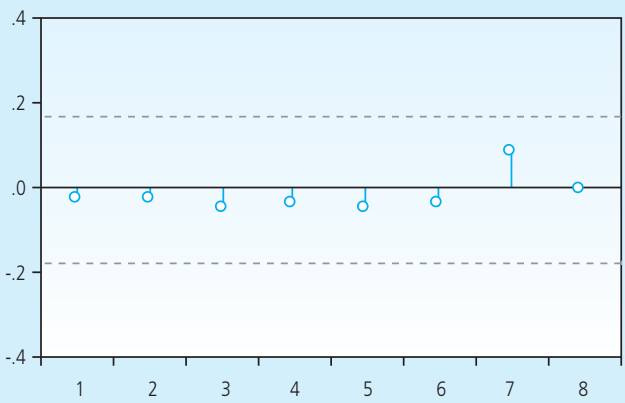



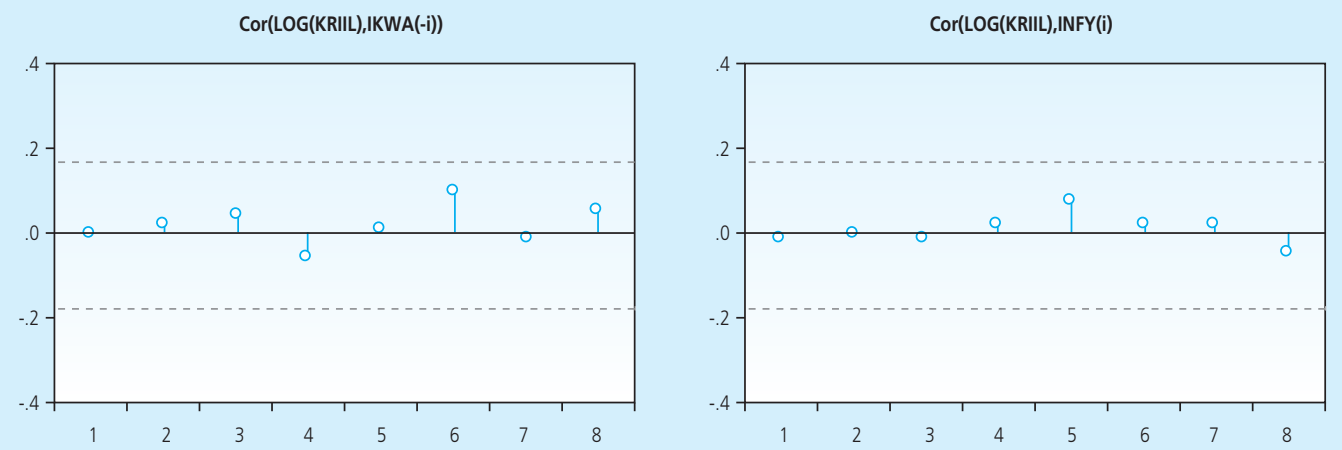

Cor(LOG(PDBRL),LOG(KRI)(-i))

Cor(LOG(PDBRL),LOG(PDBRL)(-i))
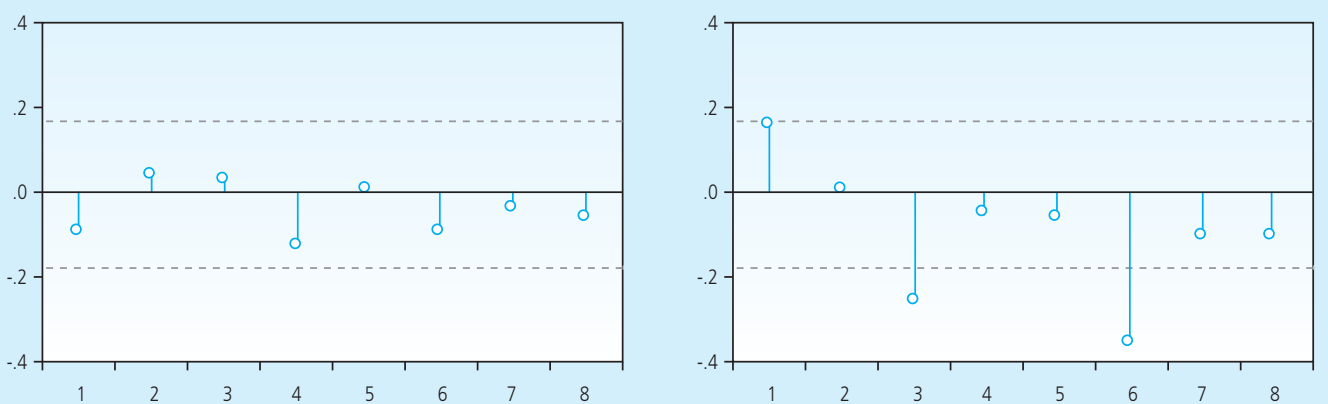

Cor(LOG(PDBRL),IKWA(-i))

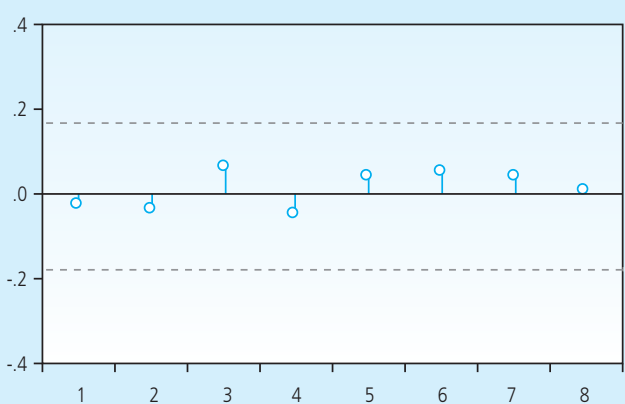

Cor(LOG(PDBRL),INFY(-i))

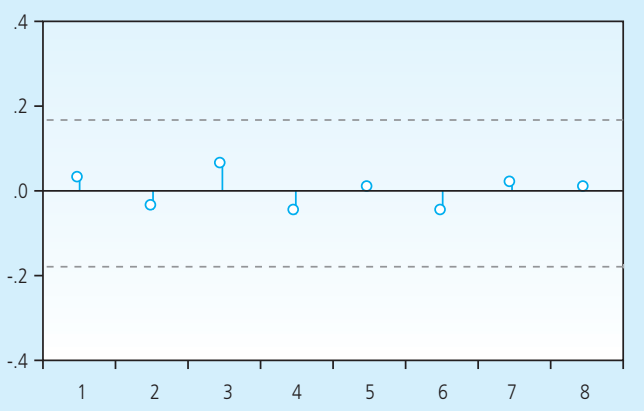

Cor(IKWA,LOG(KRIIL)(-i))

Cor(IKWA,LOG(PDBRL)(-i))
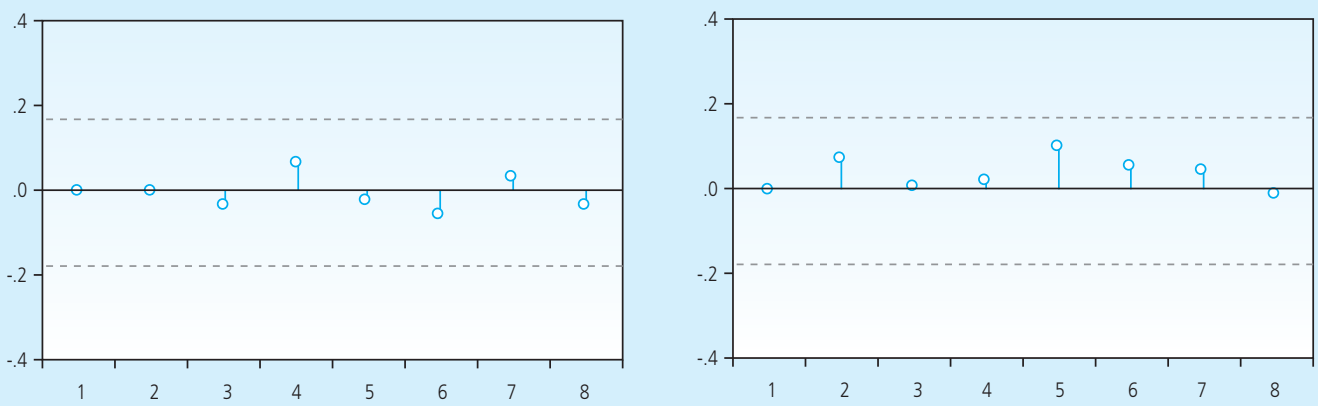

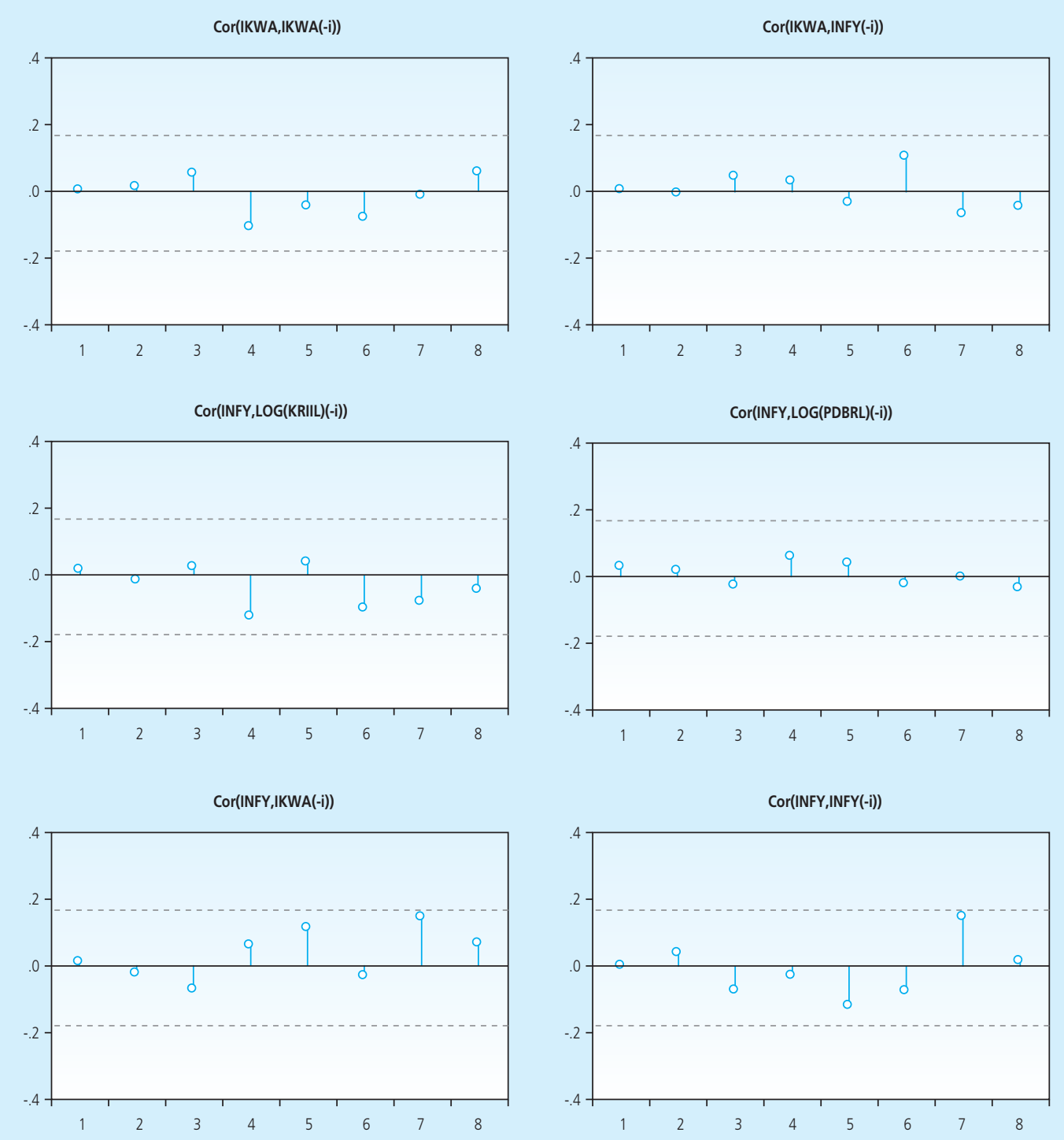


\section{Cointegration Test}

Unrestricted Cointegration Rank Test (Trace)

\begin{tabular}{|c|c|c|c|c|}
\hline Hypothesized & & Trace & 0.05 & \\
\hline No. of CE(s) & Eigenvalue & Statistic & Critical Value & Prob.** \\
\hline None * 0.263464 & 70.59464 & 47.85613 & 0.0001 & \\
\hline At most 1 * & 0.123531 & 30.84096 & 29.79707 & 0.0378 \\
\hline At most 2 & 0.095145 & 13.69994 & 15.49471 & 0.0915 \\
\hline At most 3 & 0.005389 & 0.702520 & 3.841466 & 0.4019 \\
\hline
\end{tabular}

\begin{tabular}{|c|c|c|c|c|}
\hline Hypothesized & & Max-Eigen & 0.05 & \\
\hline No. of CE(s) & Eigenvalue & Statistic & Critical Value & Prob.** \\
\hline None * 0.263464 & 39.75368 & 27.58434 & 0.0009 & \\
\hline At most 1 & 0.123531 & 17.14102 & 21.13162 & 0.1654 \\
\hline At most 2 & 0.095145 & 12.99742 & 14.26460 & 0.0785 \\
\hline At most 3 & 0.005389 & 0.702520 & 3.841466 & 0.4019 \\
\hline
\end{tabular}

